\title{
Highly efficient one-pot three-component Mannich reaction catalyzed by ZnO-nanoparticles in water
}

\author{
David Ian MaGee, ${ }^{\mathrm{a}, *}$ Minoo Dabiri, ${ }^{\mathrm{b} *}$ Peyman Salehi, ${ }^{\mathrm{c}^{*}}$ and Laleh Torkian ${ }^{\mathrm{b}}$ \\ ${ }^{a}$ Department of Chemistry, University of New Brunswick, P.O. Box 4400 Fredericton, NB Canada \\ E3B $5 A 3$ \\ ${ }^{b}$ Department of Chemistry, Faculty of Science, Shahid Beheshti University, G. C., Evin, Tehran \\ 1983916113, Iran \\ ${ }^{c}$ Department of Phytochemistry, Medicinal Plants and Drugs Research Institute, Shahid Beheshti \\ University, G. C., Evin, Tehran 1983916113, Iran \\ E-mail address: dmagee@unb.ca
}

\begin{abstract}
$\mathrm{ZnO}$-nanoparticles, as a recyclable heterogeneous catalyst, efficiently promoted the one-pot threecomponent Mannich reaction of ketones, aromatic aldehydes and amines in water to afford the corresponding $\beta$-amino carbonyl compounds in good to excellent yields and with moderate diastereoselectivity. The method offers a new modification of the Mannich reaction with a simple workup procedure.
\end{abstract}

Keywords: ZnO-nanoparticles, heterogeneous, Mannich reaction, $\beta$-amino carbonyl compounds, recyclability

\section{Introduction}

Water is used as a solvent for the development of environmentally friendly organic reactions and it is an important aspect of green chemistry. The use of water as a solvent in organic reactions signifies a remarkable benefit because it is a cheap, abundant, non-toxic and non-flammable solvent, and it is suitable for industrial production. ${ }^{1-4}$ In fact, as clearly stated by R. A. Sheldon, it is generally recognized that "the best solvent is no solvent and if a solvent (diluent) is needed it should preferably be water". 5

In recent years, heterogeneous catalysts have gained much attention, as a result of economic and environmental benefits. They make synthetic processes clean, safe and high-yielding. ${ }^{6,7}$ The use of nano-sized inorganic solid oxides as catalysts have received much attention because of their high level of chemoselectivity, environmental compatibility, simplicity of operation and their availability at low cost. Metal oxides exhibit both Lewis acid and Lewis base character at their surface. ${ }^{8}$ Metal oxide nanoparticles have different physical and chemical properties compared with bulk material 
because of their high surface area-to-volume ratio. ${ }^{9}$ In recent years, zinc oxide ( $\left.\mathrm{ZnO}\right)$, an inexpensive and easily available Lewis acid catalyst, has been widely used in organic reactions. ${ }^{10-13}$

The Mannich-type reaction is a classic protocol for the synthesis of $\beta$-amino carbonyl compounds, which are important intermediates for the construction of various nitrogen-containing natural products and pharmaceuticals and it is a reaction with high atom-economy. ${ }^{14,}{ }^{15}$ Many synthetic methods and catalysts have been reported to improve and modify this reaction. These include assistance of microwave ${ }^{16}$ or ultrasound irradiation, ${ }^{17,} 18$ and use of Lewis acids, ${ }^{19-21}$ Lewis base, ${ }^{22}$ Brønsted acids, ${ }^{23-25}$ rare metal salts, ${ }^{26,27}$ organo catalysts, ${ }^{28-30}$ ionic liquids, ${ }^{31,} 32 \mathrm{Cu}-$ nanoparticles $^{33}$ and heteropoly acids. ${ }^{34}$ Some of these methods suffer mainly from the drawbacks of long reaction times, large amounts of catalysts, expensive reagents or catalysts, toxicity, harsh reaction conditions, and low yield. Therefore we became interested in exploring the utility of $\mathrm{ZnO}$ nanoparticles as a recyclable, economical and cheap catalyst for the Mannich reaction.

\section{Results and Discussion}

Two sizes of $\mathrm{ZnO}$-nanoparticles were synthesized and their sizes were confirmed by using scanning electron microscopy (SEM). Figure 1 shows the SEM micrographs of the 105 and $1050 \mathrm{~nm} \mathrm{ZnO}$ nanoparticles (a, c) and their size distribution (b, d), respectively. The ZnO-nanoparticles, as seen in the SEM images, had an average size of 105 and $1050 \mathrm{~nm}$, respectively. The ZnO-nanoparticles were prepared from zinc acetate dihydrate.
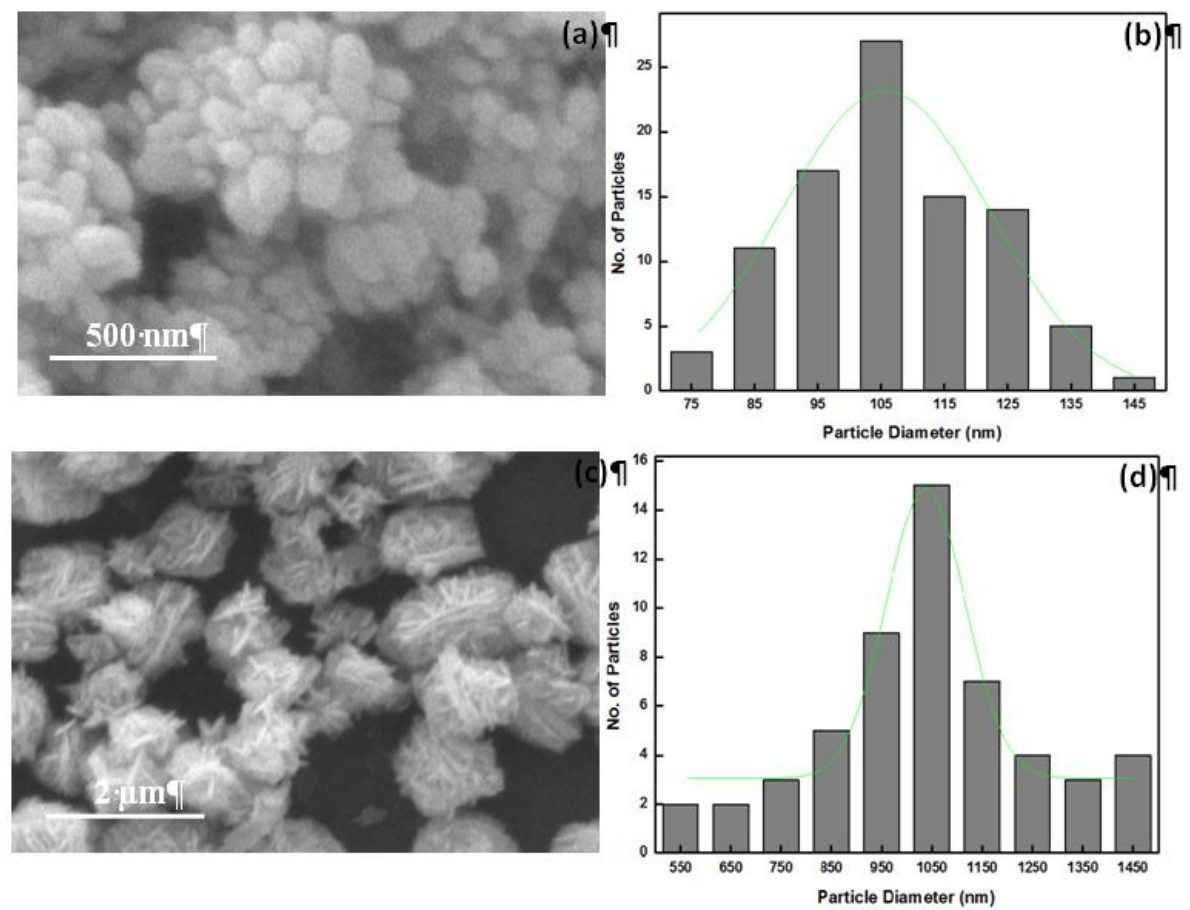

Figure 1. SEM micrographs of the 105 and $1050 \mathrm{~nm} \mathrm{ZnO-nanoparticles} \mathrm{(a,} \mathrm{c)} \mathrm{and} \mathrm{their} \mathrm{size}$ distribution $(b, d)$. 
In this Letter, we report a rapid and efficient method for the one-pot Mannich reaction of aldehydes, ketones and amines in the presence of $\mathrm{ZnO}$-nanoparticles (Scheme 1).<smiles>[R][R]1ccc(C=O)cc1</smiles>

Scheme 1. Synthesis of $\beta$-amino ketones via three-component Mannich reaction by $\mathrm{ZnO}$ nanoparticles $(105 \mathrm{~nm})$.

Initially, several different common Lewis acids were screened for their ability to catalyze the three component Mannich reaction and 4-chlorobenzaldehyde, aniline and cyclohexanone were selected as a model. As shown in Table 1, common Lewis acids such as $\mathrm{ZnCl}_{2}, \mathrm{ZnSO}_{4}$ and $\mathrm{CuCl}_{2}$ did not furnish the desired product (Table 1,entries 2-4).<smiles>Nc1ccccc1</smiles>

Table 1. Optimization of three-component Mannich reaction conditions ${ }^{\mathrm{a}}$

\begin{tabular}{|c|c|c|c|c|c|}
\hline Entry & Catalyst & Solvent & Temp. & Time (h) & Yield $(\%)^{\mathrm{a}}$ \\
\hline 1 & No. Cat & $\mathrm{EtOH}$ & $\mathrm{rt}$ & 24 & NR \\
\hline 2 & $\mathrm{ZnCl}_{2}$ & $\mathrm{EtOH}$ & $\mathrm{rt}$ & 24 & NR \\
\hline 3 & $\mathrm{ZnSO}_{4}$ & $\mathrm{EtOH}$ & $\mathrm{rt}$ & 24 & NR \\
\hline 4 & $\mathrm{CuCl}_{2}$ & $\mathrm{EtOH}$ & $\mathrm{rt}$ & 24 & NR \\
\hline 5 & $\mathrm{~A}(1 \mathrm{mmol})$ & $\mathrm{MeOH}$ & $\mathrm{rt}$ & 24 & 20 \\
\hline 6 & A $(1 \mathrm{mmol})$ & $\mathrm{EtOH}$ & $\mathrm{rt}$ & 24 & 20 \\
\hline 7 & A $(1 \mathrm{mmol})$ & $\mathrm{CH}_{2} \mathrm{Cl}_{2}$ & $\mathrm{rt}$ & 24 & Trace \\
\hline 8 & $\mathrm{~A}(1 \mathrm{mmol})$ & $\mathrm{CH}_{3} \mathrm{CN}$ & $\mathrm{rt}$ & 24 & Trace \\
\hline 9 & $\mathrm{~A}(1 \mathrm{mmol})$ & $\mathrm{H}_{2} \mathrm{O}$ & $\mathrm{rt}$ & 24 & 40 \\
\hline 10 & $\mathrm{~A}(1 \mathrm{mmol})$ & $\mathrm{EtOH}$ & $60^{\circ} \mathrm{C}$ & 10 & 78 \\
\hline 11 & $\mathrm{~A}(1 \mathrm{mmol})$ & $\mathrm{CH}_{3} \mathrm{CN}$ & $60^{\circ} \mathrm{C}$ & 10 & 75 \\
\hline 12 & $\mathrm{~A}(1 \mathrm{mmol})$ & $\mathrm{H}_{2} \mathrm{O}$ & $60^{\circ} \mathrm{C}$ & 10 & 86 \\
\hline 13 & No.Cat & $\mathrm{H}_{2} \mathrm{O}$ & $60^{\circ} \mathrm{C}$ & 10 & Trace \\
\hline 14 & $\mathrm{~A}(0.625 \mathrm{mmol})$ & $\mathrm{H}_{2} \mathrm{O}$ & $60^{\circ} \mathrm{C}$ & 10 & 83 \\
\hline 15 & $\mathrm{~A}(0.5 \mathrm{mmol})$ & $\mathrm{H}_{2} \mathrm{O}$ & $60^{\circ} \mathrm{C}$ & 10 & 85 \\
\hline
\end{tabular}


Table 1. Continued

\begin{tabular}{cccccc}
\hline Entry & Catalyst & Solvent & Temp. & Time $(\mathrm{h})$ & Yield(\%)a \\
\hline 16 & $\mathrm{~A}(0.25 \mathrm{mmol})$ & $\mathrm{H}_{2} \mathrm{O}$ & $60{ }^{\circ} \mathrm{C}$ & 10 & 80 \\
17 & $\mathrm{~B}(0.5 \mathrm{mmol})$ & $\mathrm{H}_{2} \mathrm{O}$ & $60{ }^{\circ} \mathrm{C}$ & 10 & 75 \\
18 & $\mathrm{~B}(1 \mathrm{mmol})$ & $\mathrm{H}_{2} \mathrm{O}$ & $60^{\circ} \mathrm{C}$ & 10 & 78 \\
\hline
\end{tabular}

${ }^{a}$ Reaction conditions: 4-chlorobenzaldehyde $(1 \mathrm{mmol})$, aniline $(1 \mathrm{mmol})$, cyclohexanone $(1.5$ mmol), $\mathrm{ZnO}$-nanoparticle as a catalyst and solvent $(10 \mathrm{~mL}) .{ }^{\mathrm{b}}$ Catalyst: $\mathrm{A}$ and $\mathrm{B}, \mathrm{ZnO}$ with an average size of $105 \mathrm{~nm}$ and $1050 \mathrm{~nm}$, respectively.

For $\mathrm{ZnO}$, the results demonstrated that $\mathrm{H}_{2} \mathrm{O}$ was the best medium in comparison with $\mathrm{EtOH}$, $\mathrm{CH}_{2} \mathrm{Cl}_{2}$ and $\mathrm{CH}_{3} \mathrm{CN}$; therefore, $\mathrm{H}_{2} \mathrm{O}$ was selected as the solvent of choice for this reaction (Table 1, entries 5-9). Raising the temperature to $60{ }^{\circ} \mathrm{C}$ also showed an increase in the yield of desired product (Table 1, entries 10-12). Then, the effect of catalyst loading was examined (Table 1, entries 14-16). It was found that $0.5 \mathrm{mmol}$ of $\mathrm{ZnO}$-nanoparticles $(105 \mathrm{~nm})$ was sufficient to drive the reaction to completion and an $85 \%$ yield was realized (Table 1, entry 15). Higher amounts of the catalyst gave similar results. It was also observed that the catalytic effect of nanoparticles was dependent on their size (Table 1, entries 15 and 17) and the maximum yield was obtained for the catalyst with an average particle diameter of about $105 \mathrm{~nm}$.

With optimization complete, the scope of the reaction was examined. It was quickly realized that this procedure was applicable to a wide range of different aromatic aldehydes and amines including electron-withdrawing and electron-donating groups, providing an easy access to $\beta$-amino ketones 1-18 in good to excellent yields (74-93\%) and with anti-selectivity. The results are summarized in Table 2 .

Table 2. Synthesis of $\beta$-amino ketones via a threee-component Mannich reaction

\begin{tabular}{cccccc}
\hline Entry & $\mathrm{R}_{1}$ & $\mathrm{R}_{2}$ & ${\text { Yield }(\%)^{\mathrm{a}}}$ & anti:syn $^{\mathrm{b}}$ & $\mathrm{Mp}\left({ }^{\circ} \mathrm{C}\right)$ \\
\hline 1 & $\mathrm{H}$ & $\mathrm{H}$ & 86 & $71: 29$ & $115-116^{35}$ \\
2 & $\mathrm{H}$ & $4-\mathrm{NO}_{2}$ & 89 & $69: 31$ & Oil $^{18}$ \\
3 & $\mathrm{H}$ & $4-\mathrm{Cl}$ & 85 & $77: 23$ & $135-136^{35}$ \\
4 & $\mathrm{H}$ & $3-\mathrm{NO}_{2}$ & 90 & $73: 27$ & $121-122^{36}$ \\
5 & $\mathrm{H}$ & $4-\mathrm{Me}$ & 78 & $63: 37$ & $114-116^{18}$ \\
6 & $\mathrm{H}$ & $3-\mathrm{F}$ & 83 & $72: 28$ & $167-169^{40}$ \\
7 & $4-\mathrm{Cl}$ & $4-\mathrm{NO}_{2}$ & 92 & $61: 39$ & $168-170^{36}$ \\
8 & $4-\mathrm{Cl}$ & $4-\mathrm{Cl}$ & 87 & $74: 26$ & $94-96^{35}$ \\
\hline
\end{tabular}


Table 2. Continued

\begin{tabular}{cccccc}
\hline Entry & $\mathrm{R}_{1}$ & $\mathrm{R}_{2}$ & ${\text { Yield }(\%)^{\mathrm{a}}}$ & anti:syn $^{\mathrm{b}}$ & $\mathrm{Mp}\left({ }^{\circ} \mathrm{C}\right)$ \\
\hline 9 & $4-\mathrm{Cl}$ & $2-\mathrm{Cl}$ & 86 & $79: 21$ & $95-97^{37}$ \\
10 & $4-\mathrm{Cl}$ & $3-\mathrm{NO}_{2}$ & 92 & $69: 31$ & $127-128^{35}$ \\
11 & $4-\mathrm{Cl}$ & $\mathrm{H}$ & 80 & $70: 30$ & $134-136^{35}$ \\
12 & $4-\mathrm{Cl}$ & $4-\mathrm{OMe}$ & 89 & $67: 33$ & $122-124^{35}$ \\
13 & $3,4-(\mathrm{Cl})_{2}$ & $2,4-(\mathrm{Cl})_{2}$ & 85 & $66: 34$ & $135-137^{34}$ \\
14 & $4-\mathrm{NO}_{2}$ & $\mathrm{H}$ & 75 & $70: 30$ & $121-123^{38}$ \\
15 & $4-\mathrm{NO}_{2}$ & $4-\mathrm{Cl}$ & 78 & $41: 59$ & $170-172$ \\
16 & $4-\mathrm{NO}_{2}$ & $3-\mathrm{NO}_{2}$ & 81 & $66: 34$ & $161-163$ \\
17 & $4-\mathrm{Me}_{12}$ & $4-\mathrm{Cl}$ & 93 & $71: 29$ & $118-120^{39}$ \\
18 & $3-\mathrm{NO}_{2}$ & $4-\mathrm{Cl}$ & 74 & $46: 54$ & $183-185$ \\
\hline
\end{tabular}

${ }^{a}$ Yields of isolated product. ${ }^{b}$ Diastereomeric ratio measured by ${ }^{1} \mathrm{H}$ NMR spectroscopic analysis of the crude reaction mixture.

In the investigation of various derivatives of benzaldehyde, it was found that aldehydes with electron-withdrawing groups were, not surprisingly, more active (Table 2, entries 7, 10). Furthermore, although less reactive, electron-rich aromatic aldehydes also produced the desired compounds in good yields (Table 2, entry 16).

The reusability of the catalyst is an important factor from economical and environmental points of view. For this reason, the reusability of the $\mathrm{ZnO}$-nanoparticles was examined in the reaction of 4chlorobenzaldehyde, aniline and cyclohexanone under the optimized reaction conditions. It was found that the $\mathrm{ZnO}$-nanoparticles could be reused three to four times by separating them from the reaction mixture through filtration and by washing with ethanol and drying. The results of recycling the catalyst are summarized in Table 3.

Table 3. Reusability of $\mathrm{ZnO}$-nanoparticles in the synthesis of a $\beta$-amino ketone

\begin{tabular}{ccccc}
\hline $\begin{array}{c}\text { No. of } \\
\text { Recycles }\end{array}$ & Fresh & Run 2 & Run 3 & Run 4 \\
\hline Yields (\%) & 85 & 85 & 83 & 75 \\
\hline
\end{tabular}

${ }^{a}$ Reaction conditions: 4-chlorobenzaldehyde (1 mmol), aniline (1 mmol), cyclohexanone (1.5 mmol), $0.5 \mathrm{mmol} \mathrm{ZnO-nanoparticles} \mathrm{(105} \mathrm{nm),} \mathrm{H}_{2} \mathrm{O} ; 60{ }^{\circ} \mathrm{C}$. 


\section{Conclusions}

In summary, the aforementioned protocol presents a very simple, efficient and practical method for the three-component Mannich reaction with a reusable $\mathrm{ZnO}$-nanoparticle as a catalyst in $\mathrm{H}_{2} \mathrm{O}$. The high yield, simple procedure, good functional group tolerance, ease of handling and cost efficiency of the catalyst, environmental friendliness and effective reusability of catalyst are the major advantages of this work. In addition, this strategy is adaptive for the synthesis of a diverse set of $\beta$ amino ketones.

\section{Experimental Section}

General. NMR spectra were measured in $\mathrm{CDCl}_{3}$ on a Bruker DRX-300 Avance spectrometer at 300.13 and $75.47 \mathrm{MHz}$, respectively. Scanning electron microscopy (SEM) of the particles was carried out using a Philips XLO SEM instrument. Samples were prepared by dispensing drops of an aqueous suspension of particles on to a glass plate. This was allowed to dry at room temperature and was then coated with a thin Au film. All commercially available chemicals were obtained from commercial suppliers and used without further purification.

\section{Preparation of zinc oxide with an average size of $105 \mathbf{~ n m}$}

Zinc acetate dihydrate $(1 \mathrm{mmol}, 0.219 \mathrm{~g})$ was ground for $5 \mathrm{~min}$ and then mixed with $\mathrm{NaOH}(4$ $\mathrm{mmol}, 0.16 \mathrm{~g}$ ) under solid-state reaction conditions. The mixture was ground for $30 \mathrm{~min}$ in a mortal and pestle and then the product was washed with deionized $\mathrm{H}_{2} \mathrm{O}$ and $\mathrm{EtOH}$ to remove the byproducts. The final product was dried at $80{ }^{\circ} \mathrm{C}$ for $1 \mathrm{~h}$, and then calcined at $600{ }^{\circ} \mathrm{C}$ for $2 \mathrm{~h}$ to decompose $\mathrm{Zn}(\mathrm{OH})_{2}$ into $\mathrm{ZnO}$ and $\mathrm{H}_{2} \mathrm{O} .{ }^{13}$

\section{Preparation of zinc oxide with an average size of $1050 \mathrm{~nm}$}

Zinc acetate dihydrate $(1 \mathrm{mmol}, 0.219 \mathrm{~g})$ was dissolved in methanol $(10 \mathrm{~mL})$ and was added to a $\mathrm{NaOH}$ solution $(5 \mathrm{mmol}, 0.2 \mathrm{~g}$ in $50 \mathrm{~mL}$ of $\mathrm{MeOH}$ ) while it was continuously stirred. The resulting solution was then heated at reflux for 3 hours, cooled and after three hours of constant stirring, a milky white solution was obtained. The particles were then separated by centrifugation and washed with deionized water and methanol. The solid residue was calcined at $600{ }^{\circ} \mathrm{C}$ for $2 \mathrm{~h}$ and the size, as well as the size distribution for these particles, was calculated from SEM images.

\section{General procedure for Mannich reactions catalyzed by ZnO-nanoparticle (105 nm and 1050 $\mathrm{nm}$, respectively) in water}

To a mixture of cyclohexanone $(1.5 \mathrm{mmol})$, arylaldehyde $(1 \mathrm{mmol})$ and arylamine $(1 \mathrm{mmol})$ in water $(10 \mathrm{~mL}), \mathrm{ZnO}$-nanoparticles $(0.5 \mathrm{mmol}, 0.04 \mathrm{~g}$ for $105 \mathrm{~nm}$ and $1050 \mathrm{~nm})$ were added. The mixture was stirred at $60{ }^{\circ} \mathrm{C}$ until the reaction was complete as monitored by TLC. The catalyst was removed by filtration and the resultant filtrate was extracted with ethyl acetate $(3 \times 15 \mathrm{~mL})$. The combined organic layers were dried over anhydrous $\mathrm{Na}_{2} \mathrm{SO}_{4}$, then the solvent was evaporated to 
give the crude product which upon crystallization from ethanol or ethyl acetate gave pure products. The catalyst recovered after filtration could be reused after simple washing by ethanol and drying. 2-((4-Nitrophenylamino)(4-chlorophenyl)methyl)cyclohexanone (Table 2, entry 15, antiisomer). $\mathrm{Mp} 170-171^{\circ} \mathrm{C}$. IR $\left(\mathrm{KBr}, \mathrm{cm}^{-1}\right) v 3380,3015,1661,1535,1340 .{ }^{1} \mathrm{H} \mathrm{NMR}\left(\mathrm{CDCl}_{3}\right) \delta 1.25-$ $2.13(\mathrm{~m}, 6 \mathrm{H}), 2.28-2.40(\mathrm{~m}, 2 \mathrm{H}), 2.91(\mathrm{~m}, 1 \mathrm{H}), 4.70$ (br s, $1 \mathrm{H}$, anti), 6.40-6.61 (m, 2H $\mathrm{Hr}_{\mathrm{Ar}}$ ), 7.25-7.35 $\left(\mathrm{m}, 4 \mathrm{H}_{\mathrm{Ar}}\right), 7.95-8.05\left(\mathrm{~m}, 2 \mathrm{H}_{\mathrm{Ar}}\right) .{ }^{13} \mathrm{C} \mathrm{NMR}\left(\mathrm{CDCl}_{3}\right) \delta 22.5,23.5,24.8,25.6,26.9,27.5,33.2,42.8$, 56.2, 58.2, 60.9, 112.9, 125.8, 129.1, 129.6, 129.8, 129.8, 131.9, 132.4, 138.2, 139.5, 152.9, 153.5, 212.9, 213.5. Anal. calcd for $\mathrm{C}_{19} \mathrm{H}_{19} \mathrm{ClN}_{2} \mathrm{O}_{3}$ : C, 63.60; H, 5.34; N, 7.81\%. Found: C, 63.53; H, 5.41; $\mathrm{N}, 7.75 \%$.

2-((4-Nitrophenylamino)(4-chlorophenyl)methyl)cyclohexanone (Table 2, entry 15, synisomer). $\mathrm{Mp} 170-172{ }^{\circ} \mathrm{C}$. IR $\left(\mathrm{KBr}, \mathrm{cm}^{-1}\right) v 3380,3015,1661,1535,1340 .{ }^{1} \mathrm{H} \mathrm{NMR}\left(\mathrm{CDCl}_{3}\right) \delta \delta$ 1.26-2.16 (m, 6H), 2.29-2.35 (m, 2H), $2.90(\mathrm{~m}, 1 \mathrm{H}), 4.83$ (br s, 1H, syn), 6.43-6.64 (m, 2H $\mathrm{H}_{\mathrm{Ar}}$ ), 7.22$7.32\left(\mathrm{~m}, 4 \mathrm{H}_{\mathrm{Ar}}\right), 7.90-7.98\left(\mathrm{~m}, 2 \mathrm{H}_{\mathrm{Ar}}\right) .{ }^{13} \mathrm{C} \mathrm{NMR}\left(\mathrm{CDCl}_{3}\right) \delta 22.9,23.8,24.3,26.0,26.9,27.9,32.9$, 43.1, 56.6, 58.9, 61.3, 111.9, 126.1, 129.9, 130.0, 130.1, 131.2, 131.5, 132.8, 137.8, 139.2, 152.2, 152.9, 213.1, 213.5. Anal. calcd for $\mathrm{C}_{19} \mathrm{H}_{19} \mathrm{ClN}_{2} \mathrm{O}_{3}$ : C, 63.60; $\mathrm{H}, 5.34 ; \mathrm{N}, 7.81 \%$. Found: C, 63.53; $\mathrm{H}, 5.41 ; \mathrm{N}, 7.75 \%$.

2-((4-Nitrophenylamino)(3-nitrophenyl)methyl)cyclohexanone (Table 2, entry 16). Mp (mixture of diastereoisomers) $161-163{ }^{\circ} \mathrm{C}$. IR $\left(\mathrm{KBr}, \mathrm{cm}^{-1}\right) v 3383,3013,1668,1529,1325 .{ }^{1} \mathrm{H}$ NMR $\left(\mathrm{CDCl}_{3}\right) \delta 1.63-2.42(\mathrm{~m}, 8 \mathrm{H}), 2.72(\mathrm{~m}, 1 \mathrm{H}), 4.53$ (br s, $0.66 \mathrm{H}$, anti) 4.82 (br s, 0.34H, syn), 6.75$7.12\left(\mathrm{~m}, 6 \mathrm{H}_{\mathrm{Ar}}\right), 7.34-7.76\left(\mathrm{~m}, 2 \mathrm{H}_{\mathrm{Ar}}\right) .{ }^{13} \mathrm{C} \mathrm{NMR}\left(\mathrm{CDCl}_{3}\right) \delta 23.7,24.5,24.9,26.4,27.1,34.8,37.7$, 54.6, 55.4, 58.9, 60.1 112.6, 113.5, 117.6, 118.3, 119.9, 121.6, 123.4, 124.6, 130.5, 131.6, 145.7, 146.8, 149.8, 151.4, 152.4, 211.9, 212.4. Anal. calcd for $\mathrm{C}_{19} \mathrm{H}_{19} \mathrm{~N}_{3} \mathrm{O}_{5}: \mathrm{C}, 61.78 ; \mathrm{H}, 5.18 ; \mathrm{N}, 11.38 \%$. Found: C, 61.69; H, 5.25; N, 11.29\%.

2-((3-Nitrophenylamino)(4-chlorophenyl)methyl)cyclohexanone (Table 2, entry 18). Mp (mixture of diastereosiomers) $183-185^{\circ} \mathrm{C}$. IR $\left(\mathrm{KBr}, \mathrm{cm}^{-1}\right) v 3375,3023,1672,1541,1328 .{ }^{1} \mathrm{H} \mathrm{NMR}$ $\left(\mathrm{CDCl}_{3}\right) \delta 1.60-2.42(\mathrm{~m}, 8 \mathrm{H}), 2.80-2.82(\mathrm{~m}, 1 \mathrm{H}), 4.61$ (br s, 0.46H, anti) 4.73 (br s, 0.54H, syn), $6.79\left(\mathrm{~m}, 2 \mathrm{H}_{\mathrm{Ar}}\right), 7.14-7.48\left(\mathrm{~m}, 6 \mathrm{H}_{\mathrm{Ar}}\right) .{ }^{13} \mathrm{C} \mathrm{NMR}\left(\mathrm{CDCl}_{3}\right) \delta 20.3,21.3,24.5,24.8,25.1,26.8,27.1$, 27.9, 55.4, 56.1, 57.5, 60.8, 112.5, 112.8, 126.1, 126.4, 128.6, 128.9, 129.4, 129.8, 138.1, 138.4, 138.7, 139.1, 152.1, 152.4, 212.3, 212.7; Anal. calcd for $\mathrm{C}_{19} \mathrm{H}_{19} \mathrm{ClN}_{2} \mathrm{O}_{3}$ : C, 63.60; $\mathrm{H}, 5.34 ; \mathrm{N}$, 7.81\%. Found: C, 63.54; H, 5.26; N, 7.90\%.

\section{Acknowledgements}

Financial support from the Research Council of Shahid Beheshti University and Catalyst Center of Excellence (CCE) is gratefully acknowledged. UNB and NSERC are acknowledged for their support.

\section{References}

1. Li, C. J. Chem. Rev. 2005, 105, 3095.

2. Dallinger, D.; Kappe, C. O. Chem. Rev. 2007, 107, 2563. 
3. Jung, Y.; Marcus, R. A. J. Am. Chem. Soc. 2007, 129, 5492.

4. Chanda, A.; Fokin, V. V. Chem. Rev. 2009, 109, 725.

5. Sheldon, R. A. J. Mol. Catal. A. 1996, 107, 75.

6. Ramesh, C.; Ravindranath, N.; Das, B. J. Org. Chem. 2003, 68, 7101.

7. Tanaka, K.; Toda, F. Chem. Rev. 2000, 100, 1025.

8. Tanabe, K.; Solid Acids and Bases, Academic Press, New York, 1970.

9. Bell, A. T. Science 2003, 299, 1688.

10. Mirjafary, Z.; Saeidian, H.; Sadeghi, A.; Moghaddam, F. M. Catal. Commun. 2008, 9, 299.

11. Hosseini-Sarvari, M.; Sharghi, H. J. Org. Chem. 2006, 71, 6652.

12. Hosseini-Sarvari, M.; Sharghi, H.; Etemad, S. Helv. Chim. Acta 2008, 91, 715.

13. Kassaee, M. Z.; Movahedi, F.; Masrouri, H. Synlett 2009, 1326.

14. Müller, R.; Goesmann, H.; Waldmann, H. Angew. Chem., Int. Ed. Engl. 1999, 38, 184.

15. Leadbeater, N. E.; Torenius, H. M.; Tye, H. Mol. Divers. 2003, 7, 135.

16. Pemberton, N.; Aberg, V.; Almstedt, H.; Westermark, A.; Almqvist, F. J. Org. Chem. 2004, 69, 7830.

17. Hu, D. Y.; Song, B. A.; Zhang, G. P.; Yang, S.; He, W.; Wu, Y. L.; Hong, Y. P.; Jin, L. H.; Liu, G. Chin. J. Org. Chem. 2005, 2, 845 .

18. Zhang, G.; Huang, Z.; Zou, J. Chin. J. Chem. 2009, 27, 1967.

19. Loh, T. P.; Liung, S.; Wei, L. L. Tetrahedron 2000, 56, 3227.

20. Komoto, I.; Kobayashi, S. J. Chem. Soc., Chem. Commun. 2001, 1842.

21. Li, H.; Zeng, H. Y.; Shao, H. W. Tetrahedron Lett. 2009, 50, 6858.

22. Takahashi, E.; Fujisawa, H.; Mukaiyama, T. Chem. Lett. 2004, 33, 936.

23. Iimura, S.; Nobutou, D.; Manable, K.; Kobayashi, S. J. Shem Soc., Chem. Commun. 2003, 9 , 1644.

24. Lu, G. P.; Cai, C. Catal. Commun. 2010, 11, 745.

25. Jafari, A. A.; Moradgholi, F.; Tamaddon, F. Eur. J. Org. Chem. 2009, 1249.

26. Wang, L.; Han, J.; Sheng, J.; Tian, H.; Fan, Z. Catal. Commun. 2005, 6, 201.

27. Yi, W. B.; Cai, C. J. Fluorine. Chem. 2006, 127, 1515.

28. Shen, W.; Wang, L. M.; Tian, H. J. Flourine Chem. 2008, 129, 267.

29. (a) List, B.; Pojarliev, P.; Biller, W. T.; Martin, H. J. J. Am. Chem. Soc. 2002, 124, 827. (b) Kidwai, M.; Jain, A.; Poddar, R.; Bhardwaj, S. Appl. Organometal. Chem. 2011, 25, 335.

30. Ibrahem, I.; Casas, J.; Córdova, A. Angew. Chem. Int. Ed. Engl. 2004, 43, 6528.

31. Akiyama, T.; Suzuki, A.; Fuchibe, K. Synlett 2005, 1024.

32. Liu, B. Y.; Zhao, D. S.; Xu, D. Q.; Xu, Z. Y. Chem. Res. Chin. Univ. 2007, 23, 163.

33. Kidwai, M.; Mishra, N. K.; Bansal, V.; Kumar, A.; Mozumdar, S. Tetrahedron Lett. 2009, 50, 1355.

34. Azizi, N.; Torkiyan, L.; Saidi, M. R. Org. Lett. 2006, 8, 2079.

35. Fang, D.; Gong, K.; Zhang, D. Z.; Liu, Z. L. Monatsh. Chem. 2009, 140, 1325.

36. Rafiee, E.; Eavani, S.; Nejad, F. K.; Joshaghani, M. Tetrahedron 2010, 66, 6858.

37. Hong, D.; Yang, Y. Y.; Wang, Y. G.; Lin, X. F. Synlett 2009, 1107. 
38. Zhang, X.; Yin, S.; Qiu, R.; Xia, J.; Dai, W.; Yu, Z.; Au, C. T.; Wong, W. Y. J. Organomet. Chem. 2009, 694, 3559.

39. Bigdelı, M. A.; Nemati, F.; Mahdavinia, G. H. Tetrahedron Lett. 2007, 48, 6801.

40. Guoi, Q. X.; Liu, H.; Guo, C.; Luo, S. W.; Gu, Y.; Gong, L. Z. J. Am. Chem. Soc. 2007, 129, 3790. 